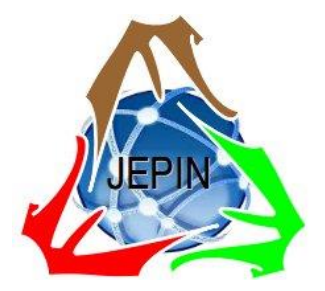

\title{
Prototipe Sistem Pemantauan Status Gizi Balita Berbasis Sistem Informasi Geografis
}

\author{
Neilcy Tjahya Mooniarsih" ${ }^{\# 1}$, Fitri Imansyah" \\ \# Program Studi Teknik Elektro, Jurusan Teknik Elektro, Fakultas Teknik, Universitas Tanjungpura \\ Jl. Prof. Dr. H. Hadari Nawawi, Pontianak 78124 \\ 1neilcy.mooniarsih@ee.untan.ac.id \\ 2fitri.imansyahdee.untan.ac.id
}

\begin{abstract}
Abstrak - Kota Pontianak merupakan salah satu daerah di Indonesia yang mengalami masalah gizi buruk pada balita. Berbagai upaya pencegahan telah dilakukan, akan tetapi masih saja terus terjadi tiap tahunnya, sehingga diperlukan pendekatan yang berbeda yaitu dengan pemetaan status gizi balita. Penelitian ini bertujuan untuk menghasilkan prototipe sistem informasi geografis yang mampu menangani data history kasus balita gizi buruk, memberikan informasi status gizi balita suatu daerah, sehingga pada akhirnya sistem ini dapat menjadi solusi alternatif bagi pemerintah dan pihak-pihak terkait untuk mendukung upaya pencegahan terjadinya kasus gizi buruk pada balita. Selain itu Sistem ini dapat membantu proses analisis data gizi balita yang berhubungan dengan data geografis suatu wilayah yang mencakup kondisi eksisting wilayah tersebut sehingga dapat menjadi indikator tambahan bagi Dinas Kesehatan dan Pemerintah Kota Pontianak serta pihakpihak terkait dalam menentukan strategi untuk perbaikan gizi balita di Kota Pontianak. Dengan menggabungkan dua komponen data tersebut diatas dalam bentuk pemetaan pemerintah Kota Pontianak akan lebih mudah dalam memantau segala sesuatu yang dapat mempengaruhi gizi balita suatu daerah sehingga dapat dengan cepat menanggulanginya.
\end{abstract}

Kata kunci - Status gizi, GIS, Gizi balita, Gizi buruk.

\section{PENDAHULUAN}

\section{A. Latar Belakang}

Masalah gizi buruk merupakan masalah yang belum bisa dituntaskan di Indonesia, termasuk di Kalimantan Barat. Selain itu masalah gizi buruk merupakan salah satu bentuk manifestasi dari adanya gangguan pada proses pertumbuhan. Tingkat perekonomian masyarakat yang di bawah rata-rata adalah salah satu faktor utama penyebabnya. Oleh sebab itu, untuk menangani masalah ini pemerintah mengadakan program perbaikan gizi di wilayah-wilayah miskin.

Program perbaikan gizi makro diarahkan untuk menurunkan masalah gizi buruk terutama di daerah miskin dengan meningkatkan keadaan gizi keluarga, meningkatkan partisipasi masyarakat, meningkatkan kualitas pelayanan gizi baik di Puskesmas maupun di
Posyandu, dan meningkatkan konsumsi energi dan protein pada balita gizi buruk. Evaluasi juga dilaksanakan dalam pelaksanaan program perbaikan gizi makro, yaitu dimulai dari evaluasi input, proses, output, dan dampak dengan tujuan untuk menilai persiapan, pelaksanaan, pencapaian, target dan prevalensi status gizi pada sasaran [1][2][3][4].

Fokus dari pengembangan sistem informasi kesehatan, khususnya di bidang gizi balita maka dianggap perlu adanya penelitian dan pemahaman untuk mengidentifikasi masalah gizi balita dalam upaya perbaikan pelayanan dan program kesehatan secara langsung. Penelitian dilakukan untuk mendapatkan data primer dari masalah gizi balita khususnya balita gizi buruk. Hasil penelitian ini memunculkan prototipe sistem yang dapat mengidentifikasi potensi masalah untuk menentukan strategi penanganan masalah yang ada yang mencakup masalah internal, masalah eksternal, dan harapan yang berkaitan dengan Gizi Balita, sehingga dapat menentukan strategi penanganan yang mampu memberikan solusi sebagai acuan untuk merancang strategi kebijakan yang tepat sebagai acuan untuk menentukan work plan.

\section{B. Teori Singkat}

Indikator paling sederhana untuk menentukan normal atau tidaknya pertumbuhan balita, yakni dengan melihat kondisi fisik atau yang disebut dengan status gizi dengan metode antropometri. Parameter yang paling mudah dan sesuai untuk mengukur status gizi balita adalah berat badan, tinggi badan atau panjang badan dan umur. Metode perhitungan menggunakan rumus z-skor dengan standar median berat badan atau tinggi badan dibagi dengan simpangan bakunya [5], sehingga secara manual perhitungan z-skor cukup rumit untuk dilakukan apalagi bila jumlah balita yang diukur status gizinya tergolong besar.

Status gizi berarti penggolongan suatu hasil pengukuran ke dalam tingkat kebutuhan gizi fisiologis seseorang [6]. Sedangkan pengertian lain menyebutkan, status gizi merupakan ekspresi dari keadaan keseimbangan dalam bentuk variabel tertentu, atau 
perwujudan dari status tubuh yang berhubungan dengan gizi dalam bentuk variabel tertentu [4][5]. Jadi intinya, terdapat suatu variabel yang diukur (misalnya berat badan dan tinggi badan) yang dapat digolongkan ke dalam kategori gizi tertentu (misalnya baik, kurang, buruk, dan sebagainya). Penilaian status gizi adalah interpretasi dari data yang didapatkan dengan menggunakan berbagai metode untuk mengidentifikasi populasi atau individu yang beresiko atau dengan status gizi buruk [7].

Pertumbuhan seorang anak bukan hanya sekedar gambaran perubahan ukuran tubuh, tapi lebih dari itu memberikan gambaran tentang keseimbangan antara asupan dan kebutuhan gizi (status gizi). Oleh karena itu, pertumbuhan merupakan indikator yang baik dari perkembangan status gizi anak [3][8][9].

Penggolongan status gizi pada tabel indeks berat badan menurut umur dan berat badan menurut tinggi badan didasarkan kepada deviasi standar (DS). Dari indeks berat badan menurut umur $(\mathrm{BB} / \mathrm{U})$, status gizi dapat digolongkan menjadi empat kelas yaitu gizi buruk $(\mathrm{BB} / \mathrm{U}$ $<-3 \mathrm{DS})$, gizi kurang $(-3 \mathrm{DS}<\mathrm{BB} / \mathrm{U}<-2 \mathrm{DS})$, gizi baik $(-$ $2 \mathrm{DS}<\mathrm{BB} / \mathrm{U}<+2 \mathrm{DS})$, dan gizi lebih $(\mathrm{BB} / \mathrm{U}>+2 \mathrm{DS})$ [3][5].

Status Gizi berdasarkan indeks berat badan menurut tinggi badan $(\mathrm{BB} / \mathrm{TB})$ juga dibagi menjadi empat kelas, yaitu kurus sekali (BB/TB < -3DS), kurus (-3 DS < $\mathrm{BB} / \mathrm{TB}<-2 \mathrm{DS})$, Normal ( $-2 \mathrm{DS}<\mathrm{BB} / \mathrm{TB}<+2 \mathrm{DS})$, dan gemuk (BB/TB > +2 DS) [3][5].

Status gizi wilayah dibagi menjadi dua macam, yaitu wilayah bebas rawan gizi (gizi baik) dan wilayah rawan gizi. Wilayah bebas rawan gizi adalah wilayah dengan prevalensi balita gizi kurang dan gizi buruk $<15 \%$. Sedangkan wilayah rawan gizi adalah wilayah yang prevalensi balita gizi kurang dan gizi buruk $>=15 \%$ [4]

Status gizi wilayah juga sangat berpengaruh dengan faktor lingkungan yang ada. Pertambahan jumlah penduduk menyebabkan kepadatan di suatu wilayah semakin meningkat. Hal tersebut berdampak signifikan dengan keterbatasan lahan bagi penduduk. Munculnya pemukiman liar, kumuh dan jauh dari standar kesehatan tidak dapat terelakkan lagi. Sehingga secara langsung dapat dirasakan bahwa pengaruh lingkungan sangat berdampak nyata bagi permasalahan gizi buruk. Hipotesa yang dapat diambil adalah semakin padat suatu daerah dengan tingkat kemiskinan dan semakin kumuh suatu lingkungan akan rentan menjadi wilayah rawan gizi.

Perkembangan aplikasi sistem informasi saat ini tidak lagi terbatas pada pengolahan data tabular dimana data disimpan ke dalam tabel-tabel basis data yang dikelola oleh perangkat lunak DBMS (database management system), tetapi telah berkembang untuk pengolahan data yang bersifat keruangan atau spasial [10].

Sistem informasi yang mempunyai kemampuan pengelolaan data spasial maupun data atribut ini kemudian dikenal sebagai Sistem Informasi Geografis-SIG (Geographical Information Systems-GIS) [11][12][13]. Para peneliti SIG telah mengemukakan beberapa definisi tentang SIG itu sendiri, antara lain [11][14][15][16]: a. sekumpulan alat bantu (tools) untuk mengumpulkan, menyimpan, memanggil, mentransformasikan, dan menampilkan data spasial dari dunia nyata. 'a powerful set of tools for collecting, storing, retrieving at will, transforming and displaying spatial data from the real world' .

b. Sebuah sistem untuk menangkap, menyimpan, memeriksa, memanipulasi, menganalisis, dan menampilkan data yang secara spasial merujuk ke permukaan bumi.'a system for capturing, storing, checking, manipulating, analyzing and displaying data which are spatially referenced to the Earth'.

c. Teknologi informasi yang menyimpan, menganalisis, dan menampilkan baik data spasial maupun data nonspasial. 'an information technology which stores, analyses, and displays both spatial and non- spatial data.

d. Sekumpulan prosedur manual atau berbasis komputer yang digunakan untuk menyimpan dan memanipulasi data yang bereferensi secara geografis. 'any manual or computer based set of procedures used to store and manipulate geographically referenced data'.

e. Sistem pendukung keputusan yang menangani penintegrasian data bereferensi spasial dalam lingkup pengambilan keputusan. 'a decision support system involving the integration of spatially referenced data in problem solving environment' .

Dari definisi tersebut di atas dapat diambil beberapa point penting bahwa SIG adalah:

- Sistem infomasi berbasis komputer

- Dapat berfungsi untuk mengumpulkan, menyimpan, mengolah, menganalisis, dan menampilkan

- Data yang bereferensi geografis (spasial) maupun nongeografis (data atribut/non-spasial) yang berguna untuk mendukung sistem pengambilan keputusan.

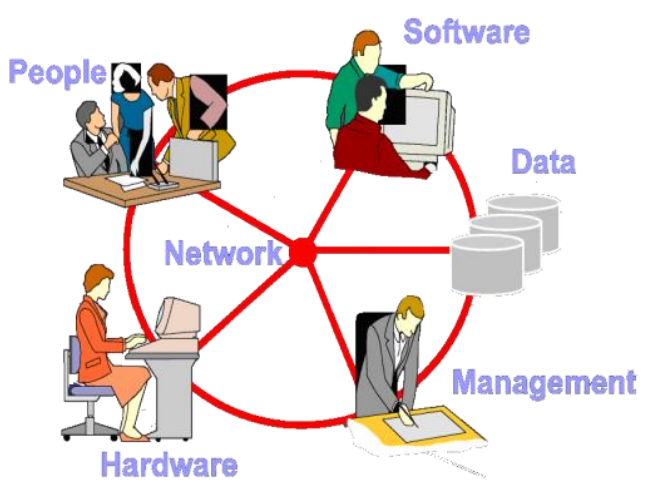

Gambar. 1 Komponen pendukung SIG

Sistem Informasi Geografis memiliki lima elemen pokok yaitu perangkat keras, perangkat lunak, data, personel/people untuk mengelola sistem, dan institusi untuk mendukung elemen tersebut (pihak manajemen).

Komponen pendukung SIG sebagai berikut [13]:

1. Perangkat keras

Perangkat keras yang sering digunakan di dalam SIG antara lain: komputer (CPU), monitor, keyboard, 
mouse, digitizer, kamera digital, printer, plotter, scanner, receiver GPS, dan sebagainya.

2. Perangkat lunak

Perangkat keras tidak akan dapat berfungsi jika tidak memiliki perangkat lunak yang bertugas mengatur kerja perangkat keras dan bertindak sebagai interface (antar muka) antara mesin dan manusia. Terdapat tiga komponen utama perangkat lunak yaitu (1) sistem operasi (Windows, UNIX, Linux, MAC/OS), (2) special system utilities (compiler, device driver, utility, library), dan (3) perangkat lunak aplikasi (MS Office, ArcView/ArcInfo, MapInfo, IDRISI, ERDAS, ER MAPPER).

3. Data dan informasi geografi

Bentuk data dan informasi geografi dapat berupa hardcopy (seperti peta dasar, foto udara, tabel, gambar grafik, dan sebagainya), maupun berupa softcopy (berbentuk file peta dijital, citra satelit, basisdata, dan sebagainya). Proses penyimpanan data dan informasi dapat dilakukan secara tidak langsung dengan mengimport dari perangkat lunak yang lain, atau dilakukan secara langsung dengan cara mendijitasi data spasialnya dari peta dan memasukkan data atributnya berdasarkan tabel, grafik, dan laporan-laporan.

4. Manajemen

Dalam hal ini manajemen merujuk kepada sumber daya manusia (brainware) yang akan mengerjakan tugas atau proyek SIG. Tanpa adanya orang-orang yang memiliki keahlian yang tepat pada tiap tingkatan, maka proyek SIG tidak dapat mencapai sasarannya.

SIG dapat mempresentasikan real world (dunia nyata) di atas monitor komputer sebagaimana lembaran peta dapat mempresentasikan dunia nyata di atas kertas [13]. SIG memiliki kekuatan lebih dan fleksibelitas daripada lembaran peta kertas. Peta merupakan representasi grafis dari dunia nyata, objek-objek yang direpresentasikan di atas peta disebut unsur peta atau map features contohnya sungai, jalan, kampung, dan lain-lain yang saling ditumpangsusunkan (overlay) satu sama lain. Karena peta mengorganisasikan unsur-unsur berdasarkan lokasilokasinya, peta sangat baik dalam memperlihatkan hubungan atau relasi yang dimiliki oleh unsur-unsurnya.

Sistem menghubungkan sekumpulan unsur-unsur peta dengan atribut-atributnya dalam satuan yang disebut layer yang akhirnya membentuk basis data. Contoh dari layerlayer yang merupakan satuan dari unsur-unsur peta tersebut dapat saling melengkapi representasi yang ditampilkan dalam satu kesatuan lembar kerja dalam satu lokasi peta seperti: batas areal kerja, kompartemen tanaman, gross area yang merupakan satuan layer polygon dilengkapi dengan adanya layer point seperti kampung, camp, menara api dan sebagainya, serta untuk layer line seperti jalan, sungai, dan sebagainya.

Perancangan data difokuskan pada struktur basis data spasial maupun non spasial. Basis data spasial dibagi ke dalam beberapa lapisan data (layer) sesuai dengan karakteristik data untuk wilayah rawan gizi Kota
Pontianak, sedangkan basis data non spasial ditentukan berdasarkan kebutuhan informasi untuk setiap kegiatan operasional.

Kebutuhan data spasial untuk perbaikan gizi di wilayah rawan gizi mencakup sedikitnya 5 (lima) lapisan data grafis (layer). Layer-layer tersebut telah dianalisis sesuai dengan kebutuhan data untuk mengembangkan prioritas aplikasi SIG Pemantauan Status Gizi Balita di Kota Pontianak.

Basis data atribut (non spasial) dirancang untuk menata dan menyimpan data untuk pengembangan SIG sistem informasi yang berkaitan dengan kebutuhan informasi pengguna. Model data yang digunakan dalam perancangan struktur data spasial dan non spasial adalah model relasional. Pemodelan data merupakan pengelompokan data dalam suatu struktur logika, yang digambarkan dengan entity relationship diagrams (ERD).

TABEL I

LAYER DATA SPASIAL

\begin{tabular}{|c|l|c|c|}
\hline No & $\begin{array}{c}\text { Nama Lapisan Data } \\
\text { (Layer) }\end{array}$ & Topologi & $\begin{array}{c}\text { Feature Attribute Table } \\
(\text { FAT })\end{array}$ \\
\hline 1 & Batas Administrasi & Polygon & Polygon Attribute Table \\
\hline 2 & Infrastruktur Jalan & Line & Arc Attribute Table \\
\hline 3 & Sungai & Line & Arc Attribute Table \\
\hline 4 & Wilayah Rawan Gizi & Polygon & Polygon Attribute Table \\
\hline 5 & Fasilitas kesehatan & Point & Point Attribute Table \\
\hline
\end{tabular}

\section{Metode PenElitian}

Metode penelitian yang akan dilakukan adalah:

a. Studi literatur

Studi literatur dilakukan guna memahami materimateri yang berkaitan dari beberapa literatur.

b. Pengumpulan Data

Pengumpulan data dilakukan dengan mengambil data dari Dinas Kesehatan Kota Pontianak dan melakukan observasi. Adapun data yang dimaksud adalah data Balita yang ditimbang, data Balita kurang Gizi, dan data kasus Balita Gizi Buruk.

c. Perancangan konseptual dari sistem yang akan dibangun

1. Perancangan Flowchart Sistem (Gambar 2)

2. Relasi Antar Tabel (Gambar3)

3. Merancang algoritma analisis data untuk menentukan wilayah rawan gizi perencanaan metode pengujian sistem.

d. Perancangan prototipe sistem

Merupakan implementasi langkah ketiga ke dalam bentuk aplikasi.

e. Pengujian dan validasi sistem

Pengujian pada sistem menggunakan metode blackbox dengan cara menggunakan data yang tidak diperbolehkan (illegal values), data yang kosong (null) dan data yang benar. Setelah pengujian dengan inputan data, tahapan selanjutnya pengujian dilakukan oleh pengguna secara langsung/UAT (User Acceptance Test) untuk memeriksa apakah sistem dapat berjalan 
dengan benar sesuai dengan yang diharapkan oleh pengguna. Pengujian ini melibatkan data real yang didapat dari pengguna tanpa memperhatikan detail internal dari sistem. Setelah itu pengguna menilai setiap fungsi yang diuji dengan memberikan skor dari tiap fungsi tersebut melalui borang yang telah dibagikan.
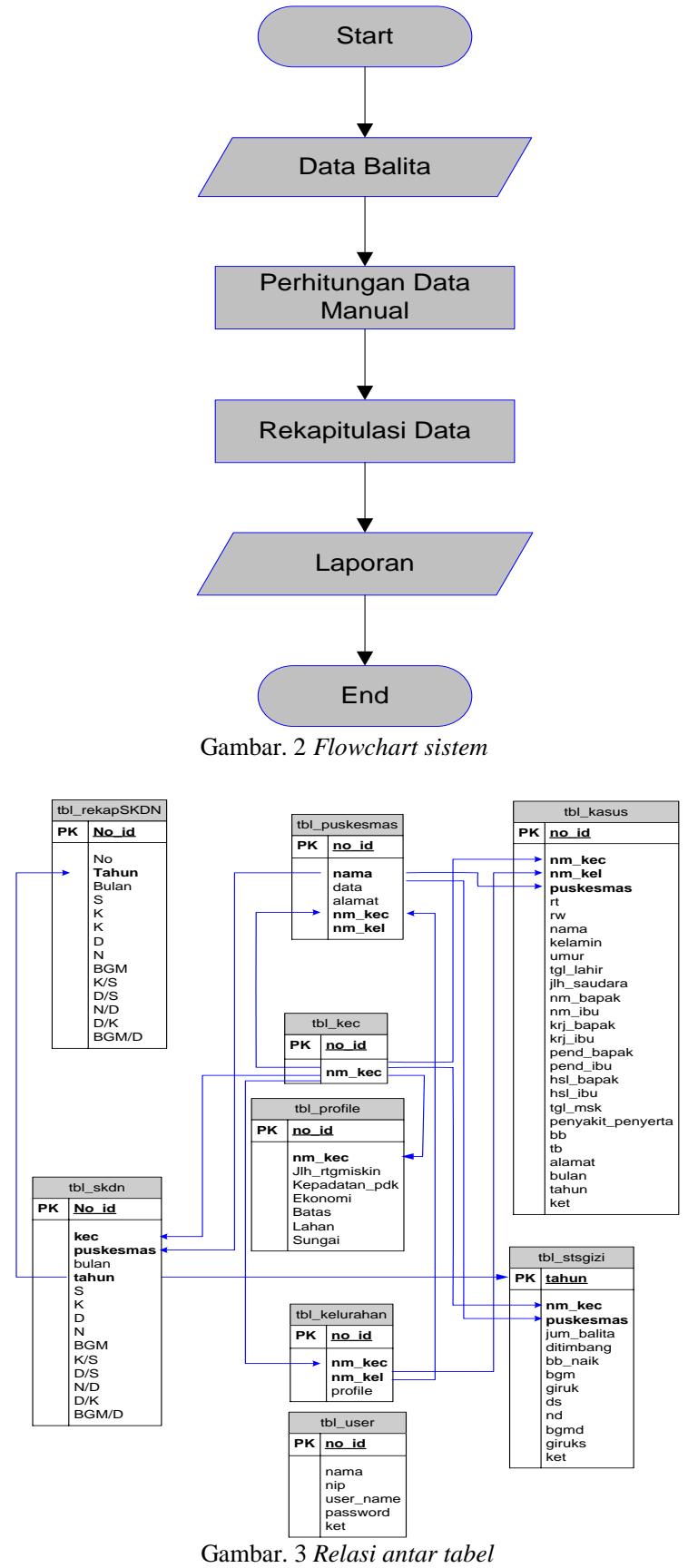

f. Analisis hasil pengujian

Analisis dilakukan setelah tahap pengujian dan validasi untuk mengetahui seberapa penting sistem yang dibangun. Hasil analisis diperoleh dengan cara melakukan perhitungan terhadap skor yang didapat dari hasil pengujian tiap fungsi. Adapun hasil dari perhitungan untuk tiap skor, dapat dilahat di bawah ini:

$$
\begin{aligned}
-\quad 4 / 4 \times 20 & =20,0 & & \text { Jika skornya } 4 \\
-\quad 3 / 4 \times 20 & =15,0 & & \text { Jika skornya } 3 \\
-\quad 2 / 4 \times 20 & =10,0 & & \text { Jika skornya } 2 \\
-\quad 1 / 4 \times 20 & =5,0 & & \text { Jika skornya } 1 \\
-\quad 0 / 4 \times 20 & =0,0 & & \text { Jika skornya 0 }
\end{aligned}
$$

Kemudian nilai tersebut dijumlahkan totalnya sesuai dengan banyaknya borang yang diisi oleh pengguna.

g. Penarikan kesimpulan

Kesimpulan dirumuskan berdasarkan pengujian yang telah dilakukan apakah sistem yang dirancang mampu memberikan informasi status gizi balita dan wilayah rawan gizi.

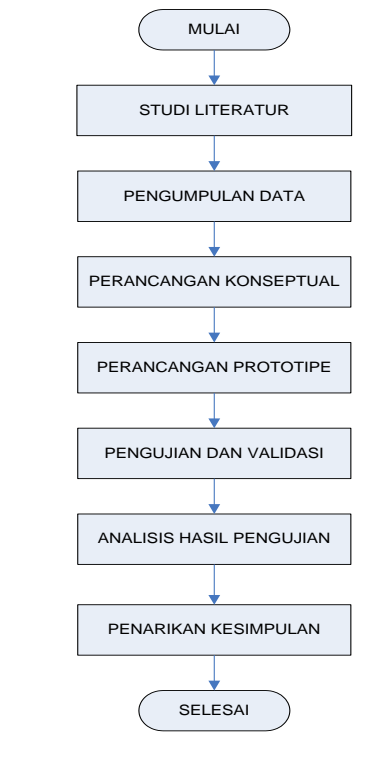

Gambar. 4 Diagram alir penelitian

\section{HASIL DAN ANALISIS}

\section{A. Prototipe Sistem}

Sistem yang telah dirancang memerlukan hardware dengan sistem operasi minimal Windows XP. Pada hardware komputer juga harus terpasang $M y S Q L, M y S Q L$ ODBC Connector dan MapObjects Runtime. Form utama digunakan untuk memanajemen peta dan mengakses formform lain pada sistem serta menampilkan hasil analisis data tabular ke dalam data spasial yang digambarkan dalam bentuk peta tematik (khusus). Antarmuka hasil perancangan form utama dapat dilihat pada Gambar 5 .

Pada bagian atas form utama terdapat empat menu utama yang di dalamnya terbagi lagi menjadi beberapa submenu. Fungsi dari masing-masing menu dapat dilihat pada Tabel 2.

Pada Gambar 6 di bagian bawah menu, terdapat dua Peta Kota Pontianak. Peta besar merupakan peta yang menampilkan seluruh layer dan peta kecil menerangkan status gizi balita melalui warna yang tampil pada setiap polygon. Peta yang ditampilkan pada form ini terdiri dari layer-layer yang disusun bertumpuk (overlay layer), dimulai dari layer kecamatan di bagian paling bawah, kemudian layer kelurahan, layer sungai, layer jalan dan 
layer puskesmas paling atas. Pengguna dapat memilih layer yang ingin diaktifkan dengan mencentang radiogroup yang berada di sebelah kanan peta. Keterangan fungsi menu dapat dilihat pada Tabel 2.

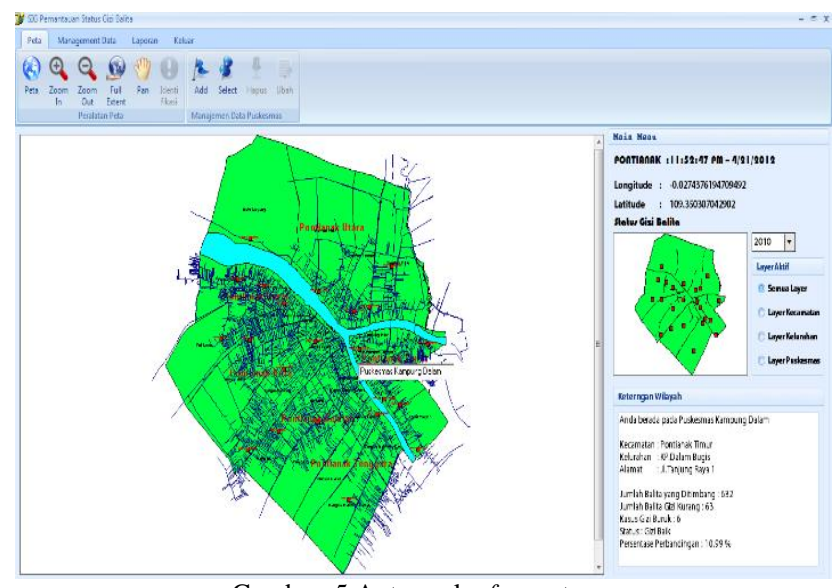

Gambar. 5 Antarmuka form utama

TABEL II

FUNGSI MENU

\begin{tabular}{|c|c|c|}
\hline Menu & Submenu & Fungsi \\
\hline \multirow[t]{2}{*}{ Peta } & Peralatan Peta & Menampilkan peralatan peta \\
\hline & Manajemen Data Puskesmas & $\begin{array}{l}\text { Menampilkan titik Puskesmas dan } \\
\text { memanajemen data Puskesmas }\end{array}$ \\
\hline \multirow[t]{4}{*}{ Manajemen Data } & Data SKDN & $\begin{array}{l}\text { Menampilkan form manajemen data } \\
\text { SKDN }\end{array}$ \\
\hline & Data Kasus Gizi Buruk & $\begin{array}{l}\text { Menampilkan form manajemen data } \\
\text { kasus gizi buruk }\end{array}$ \\
\hline & Profile Wilayah & $\begin{array}{l}\text { Menampilkan form manajemen } \\
\text { profile wilayyah }\end{array}$ \\
\hline & Data User & $\begin{array}{l}\text { Menampilkan form manajemen data } \\
\text { user }\end{array}$ \\
\hline \multirow[t]{3}{*}{ Laporan } & Laporan Status Gizi & $\begin{array}{l}\text { Menampilkan form laporan status } \\
\text { gizi dan analisis status gizi wilayah }\end{array}$ \\
\hline & Laporan Rekap SKDN & $\begin{array}{l}\text { Menampilkan form rekapitulasi data } \\
\text { SKDN }\end{array}$ \\
\hline & Diagram Statistik Gizi & $\begin{array}{l}\text { Menampilkan form grafik statistik } \\
\text { gizi balita }\end{array}$ \\
\hline Keluar & - & Keluar dari aplikasi \\
\hline
\end{tabular}

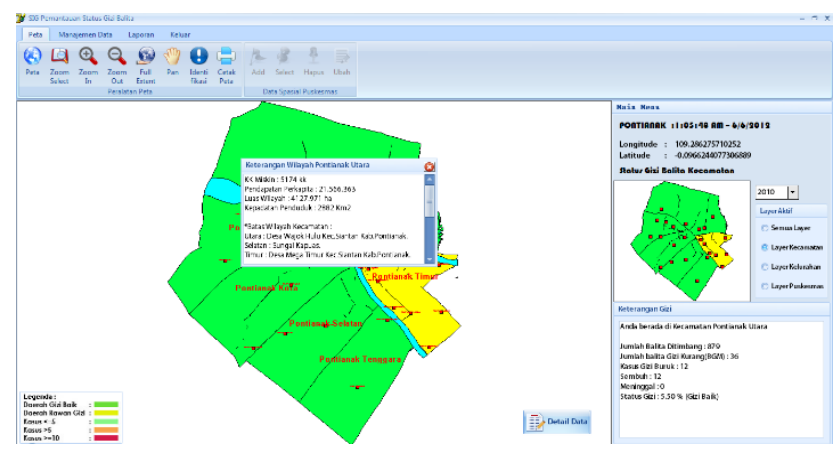

Gambar. 6 Tampilan peta status gizi

Selain itu pengguna juga dapat melihat hasil dari analisis perhitungan data tabular gizi balita dengan memilih tahun data yang akan dianalisis yang terdapat pada combobox. Hasil analisis akan diperjelas dengan menampilkan keterangan wilayah dan keterangan gizi di wilayah tersebut yang terdapat pada panel keterangan wilayah dan gizi.

\author{
Keterangan Wilayah Pontianak Utara \\ KK Miskin : 5174 kk \\ Pendapatan Perkapita : 21.566.363 \\ Luas Wilayah : 4127.971 ha \\ Kepadatan Penduduk : 2882 Km2 \\ *Batas Wilayah Kecamatan : \\ Utara : Desa Wajok Hulu Kec.Siantan Kab.Pontianak. \\ Selatan : Sungai Kapuas. \\ Timur : Desa Mega Timur Kec.Siantan Kab.Pontianak. \\ Gambar. 7 Informasi Pendukung Keterangan wilayah
}

Pada bagian kanan bawah form utama, terdapat panel Keterangan gizi (Gambar 7). Panel ini berfungsi untuk menampilkan hasil perhitungan data tabular gizi balita sesuai dengan layer aktif yang dipilih oleh pengguna. Jika pengguna mengaktifkan semua layer, maka informasi yang diberikan berupa nama kecamatan, kelurahan, alamat dan informasi seputar gizi balita pada puskesmas yang tersorot oleh pengguna serta status gizi puskesmas tersebut, sedangkan jika pengguna mengaktifkan layer kecamatan, maka informasi yang diberikan berupa nama kecamatan, keterangan status gizi dan informasi seputar gizi wilayah tersebut.

$$
\text { Keterangan Gizi }
$$

\section{Anda berada di Kecamatan Pontianak Utara}

Jumlah Balita Ditimbang : 879

Jumlah balita Gizi Kurang(BGM) : 36

Kasus Gizi Buruk : 12

Sembuh : 12

Meninggal : 0

Status Gizi : $5.50 \%$ (Gizi Baik)

Gambar. 8 Informasi hasil analisis status gizi

Pada bagian laporan user dapat menganalisis dan membuat laporan hasil analisis status gizi balita perPuskesmas (Gambar 8). Pengguna dapat melihat hasil dari analisis perhitungan dengan memasukkan tahun dan nama kecamatan yang terdapat pada combobox sebagai kriteria untuk proses perhitungan dan analisis tersebut.

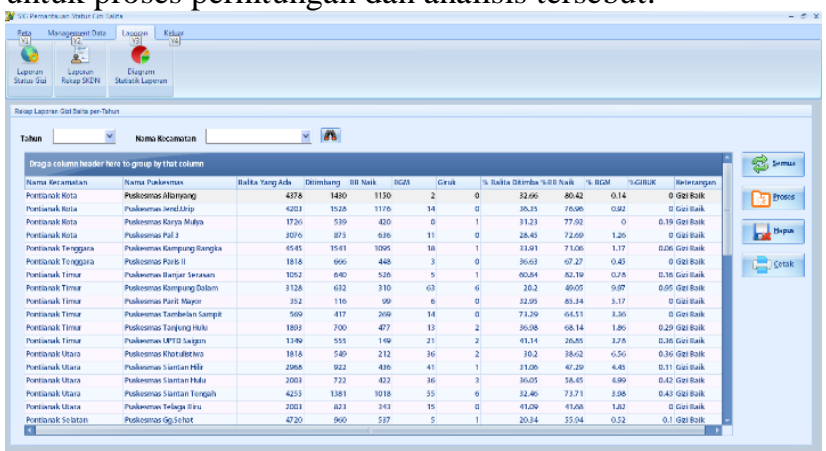

Gambar. 9 Data tabular laporan gizi balita 
Selain itu pengguna juga dapat menghapus laporan rekap per-tahun jika ada kesalahan dalam penginputan data dan mencetak hasil rekap laporan (Gambar 9).

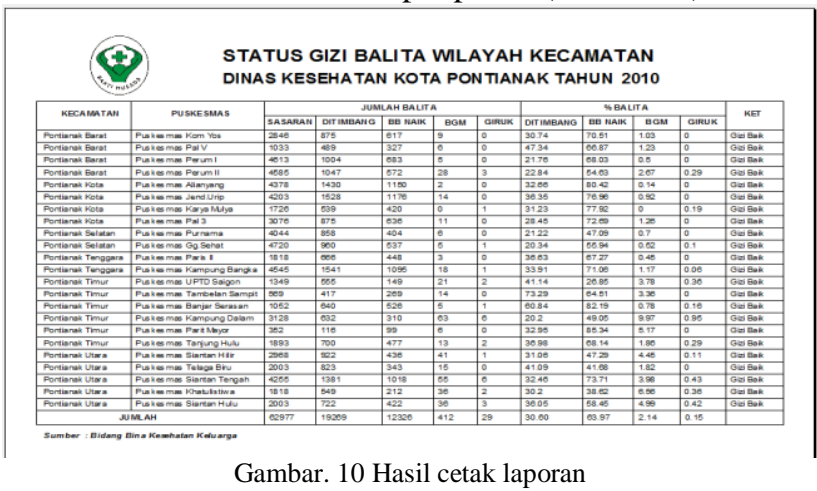

Selain laporan user juga dapat melihat grafik perkembangan keadaan gizi balita Kota Pontianak dan Kecamatan berdasarkan tahun dan bulan (Gambar 10). Pada grafik Kecamatan, pengguna dapat melihat perkembangan gizi balita yang dikelompokkan berdasarkan tahun untuk semua Kecamatan dan bulan per Kecamatan dalam satu tahun.

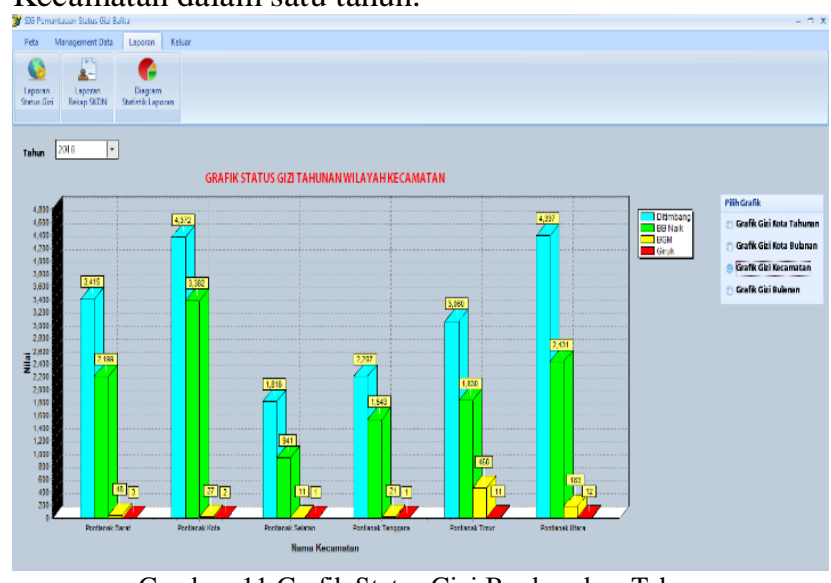

Gambar. 11 Grafik Status Gizi Berdasarkan Tahun

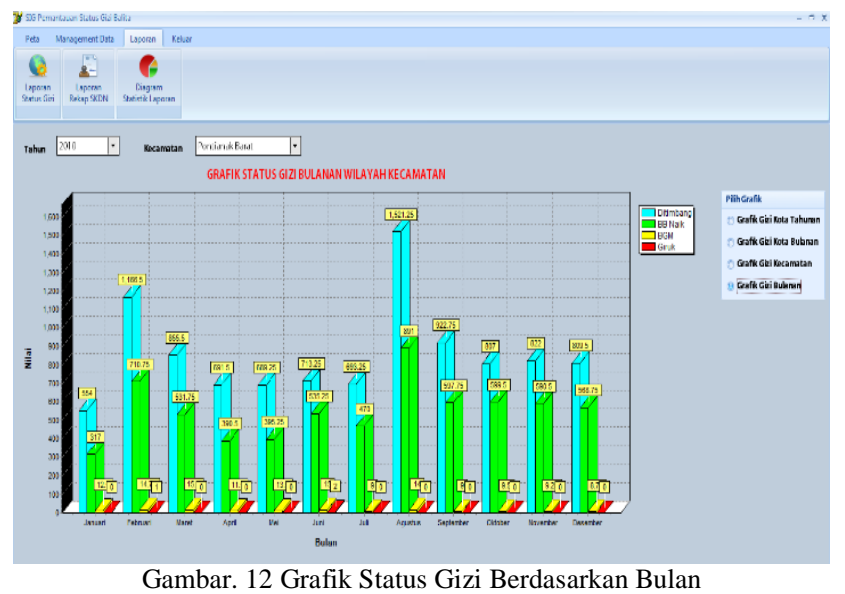

User juga dapat melihat grafik keadaan gizi balita Kota Pontianak yang dikelompokkan berdasarkan tahun dan bulan (Gambar 11 dan 12). Dari sini pengguna bisa melihat perkembangan gizi balita seluruh kota Pontianak berdasarkan Kecamatan dari tahun ke tahun dan setiap bulannya dalam kurun waktu satu tahun.

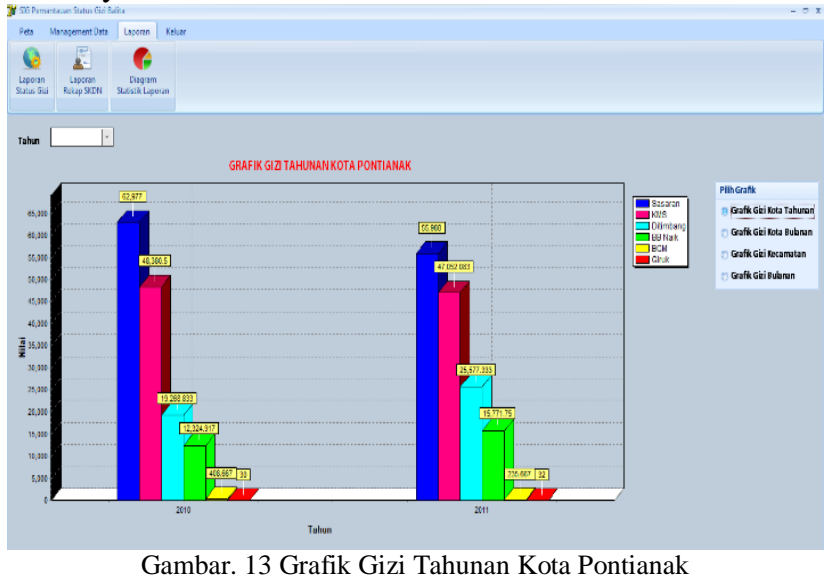

\section{B. Pengujian Prototipe Sistem}

Suatu fungsi dianggap perlu apabila jumlah penilaian fungsi tersebut dari total borang yang dibagikan ke user dalam rentang nilai 80 - 100, biasa-biasa saja 40 - 80 dan tidak perlu $0-40$. Adapun jumlah user yang menguji berjumlah 20 orang.

TABEL III

HASIL PENGUJian UAT

\begin{tabular}{|l|l|c|c|c|c|c|c|}
\hline \multirow{2}{*}{ No } & \multicolumn{1}{|c|}{ Fungsi } & \multicolumn{5}{c|}{ SKOR } & \multirow{2}{*}{ Nilai } \\
\cline { 3 - 7 } & & $\mathbf{0}$ & $\mathbf{1}$ & $\mathbf{2}$ & $\mathbf{3}$ & $\mathbf{4}$ & \\
\hline 1 & Input, Edit dan Cetak Data SKDN & & & & & 5 & 100.00 \\
\hline 2 & Input, Edit dan Cetak Data Kasus & & & & & 5 & 100.00 \\
\hline 3 & Hapus Data SKDN & & & 1 & 2 & 2 & 80.00 \\
\hline 4 & Hapus Data Kasus & & 1 & & 1 & 3 & 80.00 \\
\hline 5 & Rekap Laporan SKDN & & & & 1 & 4 & 95.00 \\
\hline 6 & Cetak Laporan SKDN & & & & & 5 & 100.00 \\
\hline 7 & Laporan dan Analisis Status Gizi & & & & & 5 & 100.00 \\
\hline 8 & Cetak Laporan Status Gizi & & & 1 & 2 & 2 & 80.00 \\
\hline 9 & $\begin{array}{l}\text { Tambah Data Spasial Puskesmas } \\
\text { Baru }\end{array}$ & & 1 & 1 & 2 & 1 & 65.00 \\
\hline 10 & $\begin{array}{l}\text { Hapus Data Spasial Puskesmas } \\
\text { Baru }\end{array}$ & & 1 & 1 & 3 & & 60.00 \\
\hline 11 & Lihat Grafik Statistik Gizi Balita & 1 & & & 2 & 2 & 70.00 \\
\hline 12 & Edit Data Profile & 3 & & 1 & 1 & & 25.00 \\
\hline
\end{tabular}

Keterangan Tabel (Tabel 3):

SKDN merupakan data balita pada kegiatan penimbangan di posyandu [3][7].

$\mathrm{S}=$ Jumlah seluruh balita yang ada di wilayah kerja posyandu

$\mathrm{K}$ = Jumlah balita yang memiliki KMS (suatu pencatatan lengkap tentang kesehatan seorang anak) pada bulan yang bersangkutan

$\mathrm{D}$ = Jumlah balita yang datang ke posyandu dan ditimbang

$\mathrm{N}=$ Jumlah Balita yang datang ke posyandu dan naik berat badannya.

Dari tabel 3 dapat dilihat bahwa fungsi yang sangat diperlukan adalah input, edit, hapus, cetak data SKDN dan 
kasus, rekap dan cetak laporan SKDN serta cetak laporan dan analisis status gizi dengan jumlah nilai rata-rata di atas 80. Sedangkan untuk tambah dan hapus data spasial puskesmas baru dianggap pengguna biasa-biasa saja, karena kemungkinan adanya penambahan puskesmas dan pemindahan puskesmas sangatlah kecil. Untuk edit data profile dan profile wilayah dianggap pengguna tidak penting, dikarenakan untuk menentukan status gizi suatu wilayah hanya mengacu kepada data SKDN dan kasus gizi buruk yang dihitung.

Berdasarkan hasil pengujian dari setiap fungsi, dapat dilihat jumlah nilai yang menganggap sistem ini penting adalah 735, biasa saja 195 dan tidak penting 25 .

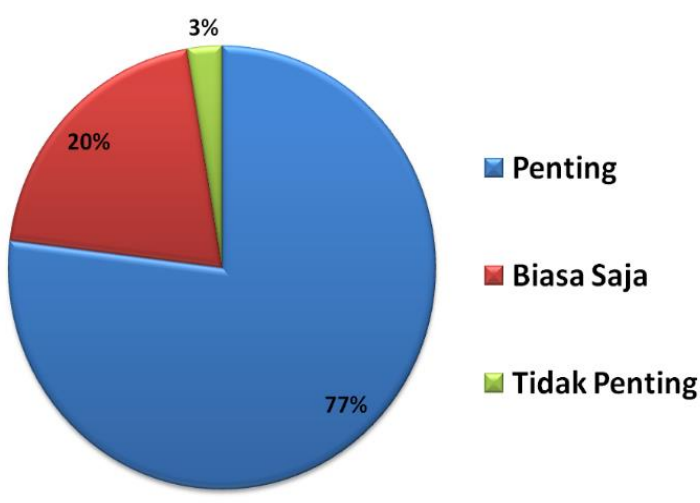

Gambar. 14 Pie Chart Hasil Pengujian UAT

Dari gambar pie chart dapat disimpulkan bahwa sistem yang dibangun berguna untuk Dinas Kesehatan Kota Pontianak dalam membantu memantau status gizi balita. Hal ini dikarenakan $77 \%$ dari pengguna yang melakukan pengujian dan penilaian menganggap sistem ini penting.

\section{KESIMPULAN}

Setelah dilakukan penelitian, maka dapat disimpulkan bahwa:

1. Salah satu pendekatan alternatif untuk memantau perkembangan gizi balita adalah pendekatan spasial yang berbasis pada data pemetaan kebumian. Dengan pendekatan ini data lokasi daerah rawan gizi maupun bebas rawan gizi direpresentasi dengan area (polygon feature) dan direlasikan dengan data atribut atau data deskriptif sehingga pengelolaan dan akurasi data menjadi lebih baik.

2. Sistem dapat membantu Dinas Kesehatan Kota Pontianak untuk menganalisis data gizi balita sehingga mempermudah Dinas Kesehatan dalam menentukan status gizi wilayah Kecamatan dan Puskesmas yang ditampilkan dalam bentuk peta dan tabel.

3. Berdasarkan hasil penilaian oleh pengguna, sistem ini dapat digunakan untuk membantu Dinas Kesehatan Kota Pontianak dalam memantau dan menyimpan data gizi balita.

4. Sistem ini dapat membantu proses analisis data gizi balita yang berhubungan dengan data geografis suatu wilayah sehingga dapat menjadi solusi bagi Dinas Kesehatan dan Pemerintah Kota Pontianak serta pihak- pihak terkait untuk mendukung upaya perbaikan gizi balita di Kota Pontianak.

5. Pemetaan penyebaran kasus gizi buruk di setiap wilayah keruangan Kota Pontianak, dapat membantu dalam usaha menganalisis sebab akibat dan pengaruh lingkungan terhadap kasus gizi buruk di setiap wilayah yang ada di Kota Pontianak.

Adapun beberapa hal yang dapat ditambahkan dalam pengembangan penulisan ini adalah sebagai berikut:

1. Data spasial dan data tabular yang dipergunakan perlu dilengkapi sehingga sistem dapat memberikan informasi dan analisis yang lebih baik.

2. Perlu keterlibatan masyarakat dalam mensukseskan sistem informasi ini yaitu dengan sistem terbaru (up date) yaitu masyarakat melaporkan secara langsung kasus gizi buruk yang ada di sekitar lingkungan mereka melalui sistem Short Message Service, yaitu sistem SMS Gate Way. Sehingga hasil pengaduan masyarakat tersebut terhadap pemantauan kasus gizi buruk dapat diperbahrui datanya dan dirujuk untuk kepentingan tindakan medis.

3. Dari hasil sistem SMS gate way tersebut diharapkan dapat menampilkan penyebaran titik-titik kasus balita gizi buruk sehingga lingkungan di sekitar balita tersebut tinggal dapat dilihat oleh pihak-pihak yang berkepentingan dalam menggunakan data gizi balita tersebut.

\section{REFERENSI}

[1] Depkes RI, 2000, Strategi dan Kebijakan Pembangunan Kesehatan Menuju Indonesia Sehat. Depkes RI. Jakarta

[2] Depkes RI, 2001, Dukungan Infromasi Untuk Manajemen Kesehatan di Kabupaten / Kotamadya, Pusat Data Kesehatan Depkes RI, Jakarta

[3] Depkes RI, 2002, Pedoman Pemantauan Status Gizi. Direktorat Bina Gizi Masyarakat Depkes RI. Jakarta

[4] Depkes RI, 2003, Indikator Indonesia Sehat 2010. Pusat Data dan Informasi Depkes RI. Jakarta

[5] Supariasa, I.D.N., Bakri, B., and Fajar, I.2002. Penilaian Status Gizi. Jakarta: EGC

[6] Hammond, K.A., 2004, Dietary and Clinical Assessment. In: Mahan, L.K., and Stump, S.E., Karuse's Food, Nutrition, and Dietary Therapy. USA: Saunders, 407-431.

[7] Hartriyanti, Y., and Triyanti, 2007. Penilaian Status Gizi. In: Syafiq, A., et al, eds. Gizi dan Kesehatan Masyarkat. Rajagrafindo Persada, 261-279.

[8] Utami, Sri, 2007, Tesis. Pengembangan Sistem Informasi Pekan Imunisasi Nasional (PIN) Berbasis Sistem Informasi Geografis (SIG) Guna Mendukung Evaluasi Program PIN di Kota Semarang. Semarang: Program Studi Magister Ilmu Kesehatan Universitas Deponegoro

[9] Taslim, Nurpudji A, 2010, Artikel. Kontroversi Seputar Gizi Buruk. Makasar: Universitas Hasanuddin.

[10] Fitri Imansyah, 2019, Pemetaan Sebaran Data Buta Aksara Dengan Sistem Informasi Geografis Dan Database Engine, Jurnal Jepin ISSN(e): 2548-9364 / ISSN(p): 2460-0741

[11] Murai, Shunji, 2006, GIS Workbook Vol I, University of Tokyo. Diterjemahkan oleh Prayitno.

[12] Nuarsa IW, 2005, Belajar Sendiri Menganalisis Data Spasial Dengan Software GIS GIS 3.3 untuk Pemula, Jakarta: PT Alex Media Computindo.

[13] Prahasta, Eddy, 2002, Konsep-konsep Dasar Informasi Geografis, Informatika, Bandung

[14] Muhajir, Ahmad, Syamsinar, dan Ilham Alimuddin. 2005. Aplikasi SIG Dalam Pembuatan Sistem Informasi Data Kota 
Makassar. Surabaya, Indonesia: Institut Teknologi Sepuluh November.

[15] Tata Sutabri, 2004, Analisa Sistem Informasi, Andi Offset, Yogyakarta.

[16] Zara, Putri Dian, 2009, Pengujian Perangkat lunak. Januari 16 2012. 